
The Journal of The Textile Institute >

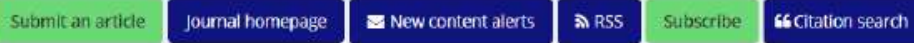

a current issue $\underline{\underline{2}}$ Browse list of issues

This journal

$>$ Aims and scope

$>$ Instructions for

authors

Society information

$>$ Journal information

> Editorial board

$>$ News \& offers

\section{Editorial board}

Editor-in-Chief:

Xungai Wang

Deakin University, Australia

Editors:

Ahmed El-Shafei - North Carolina State University, USA

Raechel Laing - University of Otago, New Zealand

Erin Parrish - East Carolina University, USA

Editorial Board:

M. D. de Araujo - University of Minho, Portuga

C. M. Carr - University of Leeds, UK

E. Devaux - ENSAIT, France

T. Ghosh - North Carolina State Univer sity, USA

T. Gries - Institut fur Textiltechnik, Germany

M. A. Hann - University of Leeds, UK

A. Hines - Manchester Metropolitan University, UK

S. Jayaraman - Georgia Institute of Technology, USA

K. Kajiwara - Otsuma Women's University, Japan

T. J. Kang - Seoul National University, Republic of Korea

P. Kiekens - University of Ghent, Belgium

P. Kilduff - California State Polytechnic University, USA

V. K. Kothari - Indian Institute of Technology, India

I. Krucinska - Technical University of Lodz, Poland

A.M. Manich - CSIC Spanish National Research Council, IQAC, Barcelona, Spain

J. Militky - Technical University of Liberec, Czech Republic

R. Paul - University of Beira Interior, Portugal

S. Russell - University of Leeds, UK

M. W. Suh - North Carolina State University, USA

X-M. Tao- Hong Kong Polytechnic University, Hong Kong

I. Tarakcioglu - Ege University, Turke

C. Warfield - Auburn University, USA

J. H. Xin - Hong Kong Polytechnic University, Hong Kong

Browse journals by subject

Area Studies

Arts

Behavioral Sciences

Bioscience

Built Environment

Communication studies

Computer Science

Development Studies

\section{Earth Sciences}

Economics, Finance, Business \& industry

Education

Engineering \& Technology

Environment \& Agriculture

Environment and Sustainability

Food Science \& Technology

Geography
Somple Our

mysical Science joumale

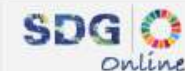

Request a free

trial today

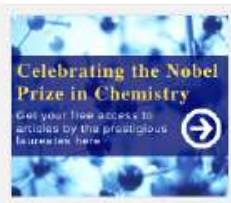


2 current issue :

Explore

- Lotertartioin

> Most reod articles

2. Most ched ortices

SOpen arcess srticles

This journal

Aims and scoos

, Iretructions far neuthar

S Sociest intomation

, journal intormation

2. Edtronol board

, News solrens

\section{Latest articles $。$}

'Latest articles' are articles accepted for publication in this journal but not yet published in a volume/issue. Articles are removed from the Latest articles list when they are pubished in a valume/1ssue. Latest articles are citable using the author(5), year of online pubilication. article title. joumal and article DO.

Article

Arroce

The effect of fabric structure on the bursting characteristics of warpknitted surgical mesh

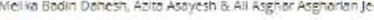

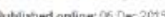

3.

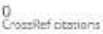

1

investigation on the effect of pigments on the texture ability and mechanical properties of polypropylene BCF yarns

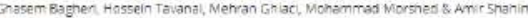
Snemsoodi

outhiched antines: cos tov 2013

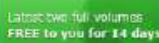

SDG 0 online

Request a free trial today

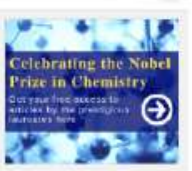

Articles

Single step green process for the preparation of antimicrobia nanotextiles by wet chemical and sonochemical methods ?

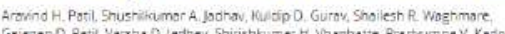

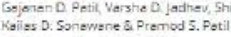

publithiod ontinar or Doc:3013

Article

Natural dyeing of merino wool fibers with Cinnamomum camphore leaves extract with mordants of biological origin: a greener approach of textile coloration

kong Gong, Luamen Jorites Rather, Qi Zhou, Wucheo Wong \& Qing L

Articles

Amproving the stiffness of multilayer 3D woven composites by the integration of shape memory alloys (SMAs) into structures ?

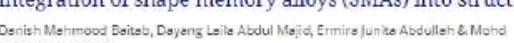

(1)

4 Neve

Goosef ntegion

Nimeers

Conshetorrions

Nimeark
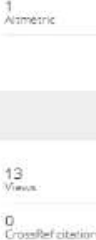

$1+\cos$

Article

An intelligent garment recommendation system based on fuzzy techniques,

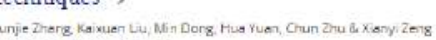

Yes

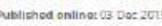

Articles

Adsorption kinetic and mechanism of reactive dye on cotton yarns with different wettability in siloxane non-acueous medium different wettability in siloxane

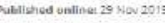

10

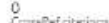

1

Article

The effect of water repellency finishing on selected performance properties of upholstery fabrics produced from chenille yarns

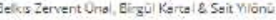
publituride entine: 27 Nov 2013

10

Cossefictiotriors 1 inters

Biological treatment of azo dyes on effluent by Neurospora sp isolated and adopted from dye contaminated site

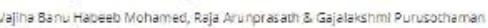

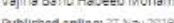


Optimization of bending and shear rigidities of woven fabrics using desirability function

Article

Textile applications of commercial photochromic dyes: parts A statistical investigation of the influence of photochromic dyes on

thermoplastic fibres using a UV-irradiation technicue >

Nanocellulose-based fibres derived from palm oil by-products and their in vitro biocompatibility analysis >

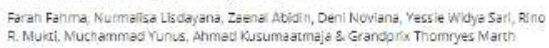

Kadja

Subjective evaluation of the rug feet feeling comfort ?

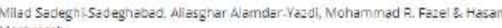

Mashroteh

Consumer experience of 3D body scanning technology and acceptance of related e-commerce market applications in Saudi Arabia ?

Publisited ontine $16 \mathrm{Nan} 209$

Hydrophobic behavior of cotton fabric activated with air atmosphericpressure plasma >

Imene Benal knaits \& Nej] uarari

Nano-TiO 2 coated cotton fahrics with temperature regulating

Articles

Processing of waste carbon and polyamide fibres for high-performance thermoplastic composites: influence of carding parameters on fibre orientarion fibre length and sliver cohesion force

Article

Presentation of different cellulosic yarn spinning wastes for decolorization of a basic dye solution,

Effects of yarn type, process history, softener type and concentration on wicking and drying properties of cotton plain knitted fabrics > Eens Cimili Duru â. Umut Kuvenç Ṣohin 
Characterization of the wool fiber physical properties of Ethiopian indigenous sheep breeds

The effect of $\mathrm{O}_{2}$ plasma treatment and PA 6 coating on digital ink-jet printing of PET non-woven fabric

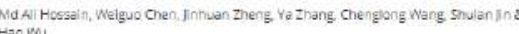

Bioinspired and green water repellent finishing of textiles using carnauba wax and layer-by-layer technique ?

Bio-inspired knitted fabric development using 3D modelling and image processing $>$

Molecular characterisation and antibacterial activity of Aloe

kooguang No, snong zhoo, Lang Warg a r Husj an zhos

Articles

A design process for a female auto-racing suit >

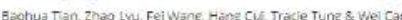

Crosefefotation

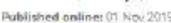

Artite incorporated wet laid wood pulp based wound dressing for severe hemorrhage

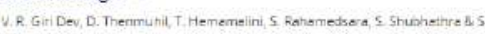

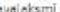

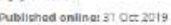

A novel technique for direct reuse of wastewater in combining scouring and bleaching of cotton fabric

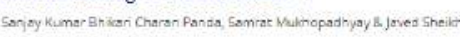

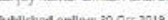

Out-of-plane permeability of 3D woven fabrics for composite structures > 
Modelling of the carding process for spunlace nonwovens with

Modelling of the carding process for spunlace nonwovens with

\section{Articles}

Structural optimization of yoga top based on 3D virtual-reality technology

$$
\text { technology > }
$$

Li Hax xo \& Wang Yongrong

A novel approach to the Poisson's ratio of the yarn

Published ontiner $170+201$

Analysis of acoustic performance of glass fiber felts after water

Article

Fabrication of core-sheath nanoyarn via touchspinning and its

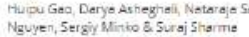

Articles

Artich

Investigation on filtration properties of polyester needle-punched dust

Models for fiber stress utilization in air jet yarns ?

Tailoring cotton fabric with wettability gradient and anisotropic penetration of liquid by spray coating

Design improvement of flexible textile aluminium-air battery >

Study on extraction technology of flavonoids from natural green cotton fiber >

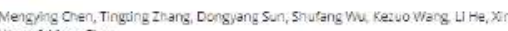

Articles

The use of natural Areca catechu dyes for silk and nylon and its halochromic effect 


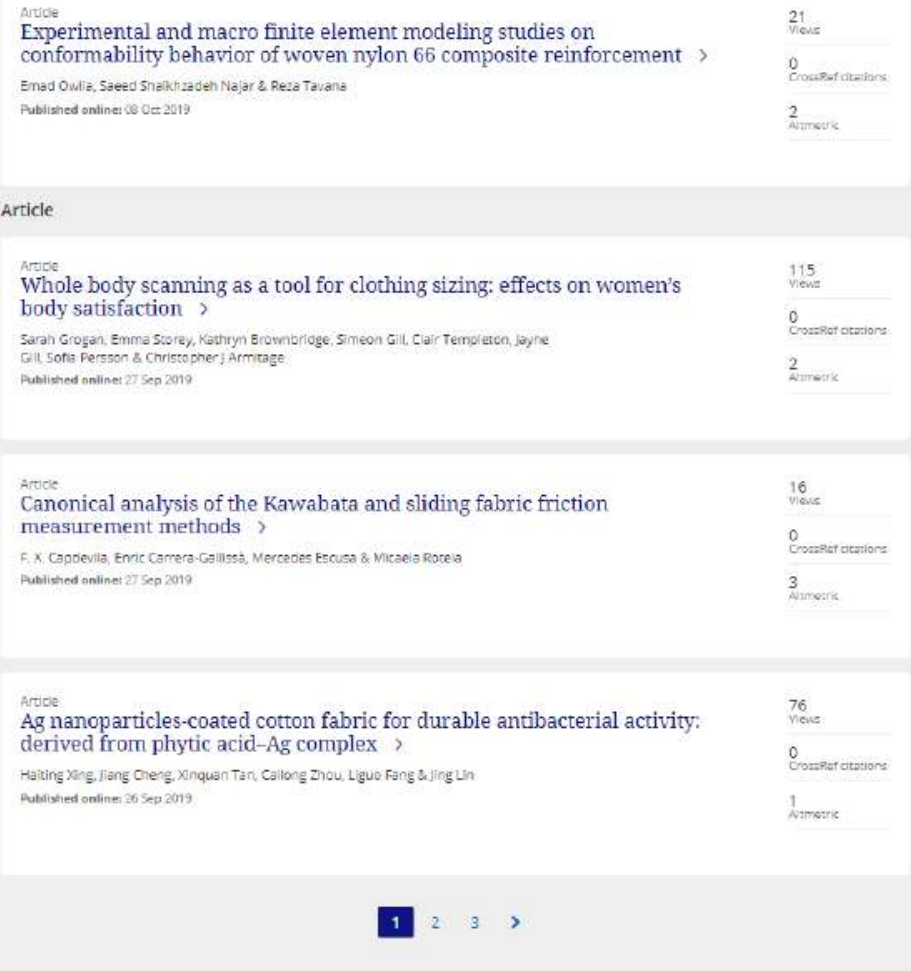

Browse journals by subject

\section{Ares Studies}

Ars

Behavioral Sciences

Bioscience

Bult Envitonment

Communiration Studier

Computer Science

Development Strudios

Information for

Authors

Ecitors

Utrorians

socetes

\section{Earth Sciences}

Economics, Finsnce, Business \& Industry

Education

Engineering \& Technology

Emwironment \& Agriculture

Erwiranment and Sustainubility

Food Sclence \& Technolegy

Geography

Open access

Overview

Open jourrals

Opon selet

Cogent OA
Health and Social Care

Humanities

Information Science

Languoge \& L literature

Law

Mathematics \& Statistics

Medidine, Dentisury, Nursing \& Alled Healch

Help and info

Help \& contad

Newsioom

Commerad services

Aljoumals
Museum and Herilage Studie

Physical Sciences

Politics \& Intemntional Relations

Social Sciences

Spers and Leisure

Tourism, Hospitality and Events

Urban Studies

Keep up to date

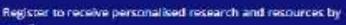

$\mathbf{E}_{\text {sigrme up }}$

$f \boldsymbol{\theta}$ in

붕 6 


\section{Nanocellulose-based fibres derived from palm oil by-products and their in vitro biocompatibility analysis}

Farah Fahma, Nurmalisa Lisdayana, Zaenal Abidin, Deni Noviana, Yessie Widya Sari, Rino R. Mukti, Muchammad Yunus, Ahmad Kusumaatmaja \& Grandprix Thomryes Marth Kadja

To cite this article: Farah Fahma, Nurmalisa Lisdayana, Zaenal Abidin, Deni Noviana, Yessie Widya Sari, Rino R. Mukti, Muchammad Yunus, Ahmad Kusumaatmaja \& Grandprix Thomryes Marth Kadja (2019): Nanocellulose-based fibres derived from palm oil byproducts and their in vitro biocompatibility analysis, The Journal of The Textile Institute, DOI: 10.1080/00405000.2019.1694353

To link to this article: https://doi.org/10.1080/00405000.2019.1694353

曲 Published online: 25 Nov 2019.

Submit your article to this journal $₫$

Q View related articles $\sqsubset$

View Crossmark data $\$ 


\title{
Nanocellulose-based fibres derived from palm oil by-products and their in vitro biocompatibility analysis
}

\author{
Farah Fahma $^{\mathrm{a}}$ (D) Nurmalisa Lisdayana ${ }^{\mathrm{b}}$, Zaenal Abidin $^{\mathrm{c}}$, Deni Noviana ${ }^{\mathrm{d}}$ (D), Yessie Widya Sari ${ }^{\mathrm{e}}$ (D), \\ Rino R. Mukti ${ }^{\mathrm{f}, \mathrm{g}}$ (D), Muchammad Yunus ${ }^{\mathrm{h}}$ (D), Ahmad Kusumaatmajai ${ }^{\mathrm{D}}$ ) and Grandprix Thomryes Marth Kadja ${ }^{\text {g.j }}$ \\ aDepartment of Agroindustrial Technology, Faculty of Agricultural Engineering and Technology, IPB University (Bogor Agricultural \\ University), Gedung Fateta, Kampus IPB Dramaga, Bogor, Indonesia; ${ }^{b}$ Department of Agroindustrial Technology, Institut Teknologi Sumatera, \\ Jalan Terusan Ryacudu, Way Hui Jati Agung, Lampung Selatan, Indonesia; 'Department of Chemistry, Faculty of Mathematics and Natural \\ Sciences, IPB University (Bogor Agricultural University), Jl. Meranti, Kampus IPB Dramaga, Bogor, Indonesia; ${ }^{\mathrm{d}}$ Department of Clinic, \\ Reproduction and Pathology, Faculty of Veterinary Medicine, IPB University (Bogor Agricultural University), Jl. Agatis, Kampus IPB Dramaga,

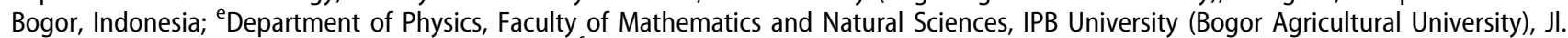 \\ Meranti, Kampus IPB Dramaga, Bogor, Indonesia; 'Department of Chemistry, Faculty of Mathematics and Natural Sciences, Institut Teknologi \\ Bandung, Jalan Ganesha no 10, Bandung, Indonesia; ${ }^{9}$ Division of Inorganic and Physical Chemistry, Institut Teknologi Bandung, Jalan \\ Ganesha no. 10, Bandung, Indonesia; ${ }^{h}$ Department of Veterinary Parasitology, Faculty of Veterinary Medicine, Airlangga University Campus \\ C, Jalan Mulyorejo, Surabaya Indonesia, Indonesia; 'Department of Physics, Faculty of Mathematics and Natural Sciences, Gadjah Mada \\ University, Sekip Utara Bulaksumur Yogyakarta, Indonesia; ${ }^{j}$ Research Center for Nanosciences and Nanotechnology, Institut Teknologi \\ Bandung, Jalan Ganesha no. 10, Bandung, Indonesia
}

\begin{abstract}
Fibres with nanocellulose isolated from oil palm empty fruit bunches (OPEFBs) were produced. Nanocellulose and PVA-nanocellulose fibres were prepared by wet spinning in an acetone coagulation bath without drawing. The addition of nanocellulose was varied from $10 \%$ to $30 \%$, to reveal the beneficial effects of nanocellulose content on the properties of produced spun-fibres. Higher concentration of nanocellulose increased the stiffness of spun-fibres. PVA and PVA-bacterial cellulose fibres were also produced as a control and for comparison, respectively. The nanocellulose fibre formed a compact structure, while PVA fibres had hollow structures. The effect of the produced spun-fibres on the biocompatibility of calf pulmonary artery endothelial cells was assayed by an MTT test. Based on the MTT assay the addition of nanocellulose increased the percentage of cell viability of the obtained spunfibres slightly. These results point towards the use of sustainable sources of nanocellulose as a beneficial and biocompatible fibre material.
\end{abstract}

\section{ARTICLE HISTORY}

Received 5 May 2019 Accepted 13 November 2019

\section{KEYWORDS}

Spun-fibres; nanocellulose; cellulose nanofibers; wet spinning; biocompatibility

\section{Introduction}

Indonesia's palm oil production in 2015 was 31.28 million tonnes and continues to grow each year. Of the 11.3 million ha of oil palm plantations, $50.77 \%$ were owned by private companies, $37.45 \%$ owned by citizen farmers and the rest were state-owned (Ministry of Agriculture of Republic of Indonesia, 2016). Unfortunately, oil palm empty fruit bunches (OPEFBs) are an abundant waste product of palm oil production that can have a negative impact on the environment. OPEFBs contain $44.4 \%$ cellulose, $30.9 \%$ hemicellulose and $14.2 \%$ lignin (Sun, Fang, Mott, \& Bolton, 1999). Given the considerable cellulose content of OPEFBs, useful applications of this waste stream may be found, such as their use as a raw material for cellulose nanofiber production.

Cellulose is a major component of plant cell walls and can be extracted from a variety of sources, including lignocellulose plants, marine animals (such as tunicates), algae, fungi and bacteria. Besides cellulose, plant cell walls also contain hemicellulose and lignin. Although wood is the main source of cellulose, currently non-wood plants are gathering increased attention from many researchers because of their abundant availability and low lignin content. Cellulose is almost never found isolated in nature but is always bound to other ingredients such as lignin and hemicellulose. Cellulose is a homopolymer of $\beta$-D-glucopyranose units linked together by $\beta-1,4$-glucosidic bonds. The building block for cellulose is a cellobiose, a dimer of glucose. The cellulose molecules are connected together through hydrogen bonding and contain about $40-70 \%$ crystallised parts, while the rest is amorphous depending on the source of cellulose (Nasir, Hashim, Sulaiman, \& Asim, 2017).

Due to biodegradability, nontoxicity and high abundance in nature, cellulose is a very interesting material for future applications, especially for medical devices. Many studies have been conducted on the application of cellulose and its derivatives in the medical field, including artificial kidney membranes, coating materials and pharmaceutical product additives (Masahiro, Megumi, Kazuhiko, Hitoshi, \& 
Takaichi, 1980; Spencer, Schmidt, Samtleben, Bosch, \& Gurland, 1985).

Nanocellulose (or cellulose nanofiber) is a general term for materials with cellulose-based nanostructures where at least one dimension has length on the nanometre scale $(1-100 \mathrm{~nm})$ (Nasir et al., 2017; Seabra, Bernardes, Fávaro, Paula, \& Durán, 2018). Cellulose nanofibers can be isolated from various lignocellulose sources, including OPEFBs. Nanocellulose from OPEFB has been successfully isolated by chemical treatment using sulfuric acid hydrolysis and mechanical treatment using a combination of ultrafine grinding and ultrasonication (Fahma, Iwamoto, Hori, Iwata, \& Takemura, 2010; Fahma, Sugiarto, Sunarti, Indriyani, \& Lisdayana, 2017).

Cellulose nanofibers (nanocellulose isolated by mechanical treatment) and cellulose nanocrystals (nanocellulose isolated by chemical treatment) can potentially be used to produce fibres, filaments and yarns. Håkansson et al. (2014) successfully produced homogeneous and fine filaments from cellulose nanofibrils by a process combining a hydrodynamic alignment with a dispersion-gel transition. Iwamoto, Isogai, and Iwata (2011) reported that wet-spun-fibres were produced from cellulose nanofibers isolated from wood and tunicate. The fibres, produced at spinning rate of $100 \mathrm{~m} / \mathrm{min}$, had a Young's modulus of $23.6 \mathrm{GPa}$, tensile strength of $321 \mathrm{MPa}$ and elongation at break of 2.2\%. Lundahl et al. (2016) also reported that the continuous filaments could be prepared by a similar method at spinning rate $7.5 \mathrm{~m} / \mathrm{min}$. The obtained filaments had tensile strength of $297 \mathrm{MPa}$ and Young's modulus of $21 \mathrm{GPa}$. Hooshmand, Aitomäki, Norberg, Mathew, and Oksman (2015) prepared continuous nanocellulose-based filaments from banana rachis by dry spinning. The strength and modulus of the obtained filaments were around 131-222 $\mathrm{MPa}$ and $7.8-12.6 \mathrm{GPa}$, respectively.

In addition to $100 \%$ nanocellulose-based materials, researchers have reported fibres or filaments derived from nanocellulose and PVA (Polyvinyl alcohol) mixtures. PVA is a synthetic polymer that is soluble in water, nontoxic, biocompatible and has excellent mechanical properties. PVA and nanocellulose can form a homogeneous mixture because both are hydrophilic. Endo, Saito, and Isogai (2013) and Peng, Ellingham, Ron Sabo, Turng, and Clemons (2014) produced PVA-nanocellulose fibres using spinning, drawing and drying processes. In the work done by Endo et al. (2013), it was reported that only $1 \mathrm{wt} \%$ TEMPO-oxidised cellulose nanofibers (TOCN) added into PVA solution produced a spinning dope to produce PVA-TOCN fibres, followed by a drawing process with maximum total draw ratio (DR) of 20 up to $230^{\circ} \mathrm{C}$. In addition, Peng et al. (2014) reported that spinning solutions were prepared by addition of various amounts of short cellulose nanofibers $(0,1,2,3$ and $6 \mathrm{wt} \%$ ) into PVA solution.

The presence of PVA in these composites enhanced the mechanical properties of the produced filaments. The success of producing nanocellulose-based filaments is a promising for future studies of new nanocellulose-based composite materials, including medical applications such as surgical thread. The main requirement for polymer biomaterials in medical applications is biocompatibility, or little to no rejection by body tissue (Nguyen, Abueva, Ho, Lee, \& Lee, 2018). The biocompatibility of these NC fibres, especially using sustainably sourced nanocellulose, has not been extensively studied.

In this study, nanocellulose-based fibres were produced by a direct wet spinning process in an acetone coagulation bath with nanocellulose isolated from OPEFBs. Spun PVA and PVA-bacterial cellulose fibres were also prepared as control and comparison, respectively. The produced wetspun-fibres were investigated using scanning electron microscopy (SEM), thermogravimetric analysis (TGA), Fourier transform infrared spectroscopy (FTIR) and X-ray diffraction (XRD). In addition, the mechanical properties of the spun-fibres were determined by tensile tests and the biocompatibility properties were assayed by an MTT test.

\section{Materials and methods}

\section{Materials}

Oil palm fibres from OPEFBs for the production of nanocellulose were obtained from PTPN VIII, Kertajaya, Lebak, West Java, Indonesia. PVA was supplied by Celvol TM Sekisui Chemical Co. ltd. Bacterial cellulose sheets were supplied by CV Graha Agri Industri Indonesia (a local company). Analytical grade sodium hydroxide was used as received. $\mathrm{H}_{2} \mathrm{O}_{2}$ and acetone were of technical grade and used without further purification.

\section{Isolation of cellulose fibres from OPEFBs}

Cellulose fibres from OPEFBs were isolated by alkali treatment using a two stage-bleaching treatment. First, OPEFBs were dipped in a $30 \% \mathrm{H}_{2} \mathrm{O}_{2}$ solution, followed by submersion in a mixture of $10 \% \mathrm{NaOH}$ and $30 \% \mathrm{H}_{2} \mathrm{O}_{2}$ (1:2). The obtained cellulose fibres were then used as starting materials for producing nanocellulose.

\section{Nanocellulose production from OPEFBs}

Nanocellulose suspensions ( $1.85 \%$ of solid content) from OPEFBs were isolated as described in our previous report using a combination of ultrafine grinding and ultrasonication (Fahma et al., 2017). Cellulose pulp with a concentration of $1-2 \%$ was prepared initially using warring blender. The suspension of cellulose fibres was then passed through an ultrafine grinder (Masuko Co., Ltd) several times at $1500 \mathrm{rpm}$. Next, the suspension was treated by ultrasonication at $40 \%$ amplitude for $30 \mathrm{~min}$. Finally, the produced nanocellulose suspension in water was stored in refrigerator to produce nanocellulose-based fibres. Bacterial cellulose (BC) also went through the same process as described to create nano-sized bacterial cellulose (NBC).

\section{Production of nanocellulose-based fibres}

PVA solution (10 wt\%) and a nanocellulose suspension in water $(1.85 \mathrm{wt} \%)$ with varying nanocellulose contents $(0,10$, 
20 and $30 \mathrm{wt} \%$ ) were mixed together until the solution was homogeneous. The mixture was spun without drawing in a $500 \mathrm{~mL}$ technical grade acetone coagulation bath using a needle with a diameter of $0.95 \mathrm{~mm}$ set on syringe and a spinning rate of $10 \mathrm{~mL} / \mathrm{min}$. After the spun-fibres were taken from the acetone coagulation bath, they were dried at room temperature for $24 \mathrm{~h}$ before being dried at $50{ }^{\circ} \mathrm{C}$ for $1 \mathrm{~h}$. The spun PVA-NBC (70:30) fibre was also prepared as comparison.

\section{Characterisation}

\section{Scanning electron microscopy observation}

The morphology of the obtained nanocellulose, including surface images and cross sections of the produced spun-fibres, were observed by a scanning electron microscope (SEM Zeiss EVOMA 10) operating at $16 \mathrm{kV}$. The samples were coated with gold to improve contrast before being observed. The diameter of nanocellulose (NC) and NBC were measured using ImageJ software using 50 different points.

\section{$X$-ray diffraction analysis}

In order to understand the structure, we conducted X-ray diffraction analysis of all samples. The sample was cut into small pieces around $1 \mathrm{~mm}$ long and the analysis was performed using an XRD Bruker D8 with a $\mathrm{K} \alpha \mathrm{Cu}(\lambda=1.54060) \mathrm{X}$-ray source set to $40 \mathrm{kV}$ and $35 \mathrm{~mA}$. The degree of crystallinity based on diffraction profile was calculated as the ratio of the area under the crystalline diffraction peaks to the total area under the curve (Wang, Sain, \& Oksman, 2007).

\section{Fourier transform infrared spectroscopy analysis}

Samples of all spun-fibres were cut into small pieces and then dried before incorporation into $\mathrm{KBr}$ pellets. FTIR spectra were obtained using a Shimadzu FTIR Prestige in transmittance mode with a resolution of $4 \mathrm{~cm}^{-1}$. Each sample was scanned 64 times.

\section{Thermogravimetric analysis}

Thermal degradation of all spun-fibres was observed using a Hitachi STA 7200 instrument. About $10 \mathrm{mg}$ of samples were observed and thermograms were obtained between $30^{\circ} \mathrm{C}$ and $600{ }^{\circ} \mathrm{C}$ at a heating rate $15^{\circ} \mathrm{C} / \mathrm{min}$ with nitrogen purge gas at a flow rate of $50 \mathrm{~mL} / \mathrm{min}$.

\section{Tensile test and degree of swelling}

The tensile tests of single spun-fibres were performed using a universal testing machine (Instron 3369P7905, USA) by applying a load cell of $50 \mathrm{~N}$ at a crosshead speed of $6 \mathrm{~mm} /$ min with three measurements each. Three of each dried single spun-fibres were swollen in deionised water at room temperature for $2 \mathrm{~h}$. The degree of swelling was calculated as:

$$
\text { Degreeofswelling }=\frac{(\text { Wet weight }- \text { Dry weight })}{\text { Dry weight }} \times 100 \%
$$

\section{In vitro biocompatibility analysis}

The biocompatibility of all spun-fibres on living tissue was identified by cell viability analysis using an MTT assay. For the 3-[4,5-dimethylthiazol-2-yl]-2,5-diphenyltetra-zolium bromide (MTT) assay, cells were grown with a concentration of 5000 cells in $100 \mu \mathrm{L}$ of growing media. All spunfibres were previously immersed in Dulbecco's Modified Eagle's Medium (D-MEM) culture media for 7 days and 14 days. The extract was added after the cell reached $50 \%$ confluence $(24 \mathrm{~h})$. The MTT test was carried out on day 3, by adding $10 \mu \mathrm{L}$ of MTT solution $(5 \mathrm{mg} / \mathrm{mL})$ per well and incubating for $4 \mathrm{~h}$ at $37^{\circ} \mathrm{C}$. Formazan crystals were dissolved in ethanol. The absorbance was measured at a wavelength of $595 \mathrm{~nm}$.

\section{Results and discussions \\ Morphology and crystallinity degree of nanocellulose from OPEFBs}

Figure 1(a) shows an SEM image of the nanocellulose from OPEFBs isolated by mechanical treatment (combination of ultrafine grinding and ultrasonication). The diameter of the obtained nanocellulose was $33.62 \pm 6.8 \mathrm{~nm}$ and their lengths were several micrometres. The diameter of the nanocellulose produced in this study was similar with the results of our previous study (Fahma et al., 2017). The only difference between this work and our previous study is the starting material for nanocellulose production. In our previous study, the method of preparing cellulose fibres using $6 \%$ $\mathrm{KOH}$ and $12 \%$ hypochlorite solution produced nanocellulose from OPEFBs with a diameter of $27.23 \pm 8.21 \mathrm{~nm}$ and a length of several micrometres. $\mathrm{H}_{2} \mathrm{O}_{2}$ treatment (see Materials and Methods) was used in this study instead of hypochlorite solution, however, because it is more environmental friendly.

Nanocellulose isolated from OPEFBs by chemical treatment using sulfuric acid hydrolysis had a thickness of $1-3.5 \mathrm{~nm}$ observed by Atomic Force Microscope (AFM) (Fahma et al., 2010). In another report, Rohaizu and Wanrosli (2017) found that nanocrystalline cellulose (NCC) from OPEFBs and microcrystalline cellulose (OPEFBsMCC) isolated via TEMPO-oxidation and ultrasonication had an average length and width of 122 and $6 \mathrm{~nm}$, respectively.

Figure 1(b) shows the SEM image of nano-sized bacterial cellulose (NBC) used to make spun-fibre as a comparison. The NBC had an average diameter of $40 \pm 9.9 \mathrm{~nm}$. NBC diameters seems more uniform than $\mathrm{NC}$ isolated from OPEFBs.

From the XRD profile of nanocellulose (Figure 1(c)), a broad peak of nanocellulose OPEFBs is visible at $15.1-16.5^{\circ}$ and a steep peak at $22.5^{\circ}$. The lattice planes $1 \overline{\mathrm{i}} 0$ and 110 appear to overlap due to low crystallinity of nanocellulose from OPEFBs. Based on the XRD profile of the nanocellulose we assign the structure as cellulose I. Generally, the XRD pattern of cellulose with high crystallinity consists of three lattice peaks corresponding to $1 \overline{\mathrm{i}} 0,110$ and 200 

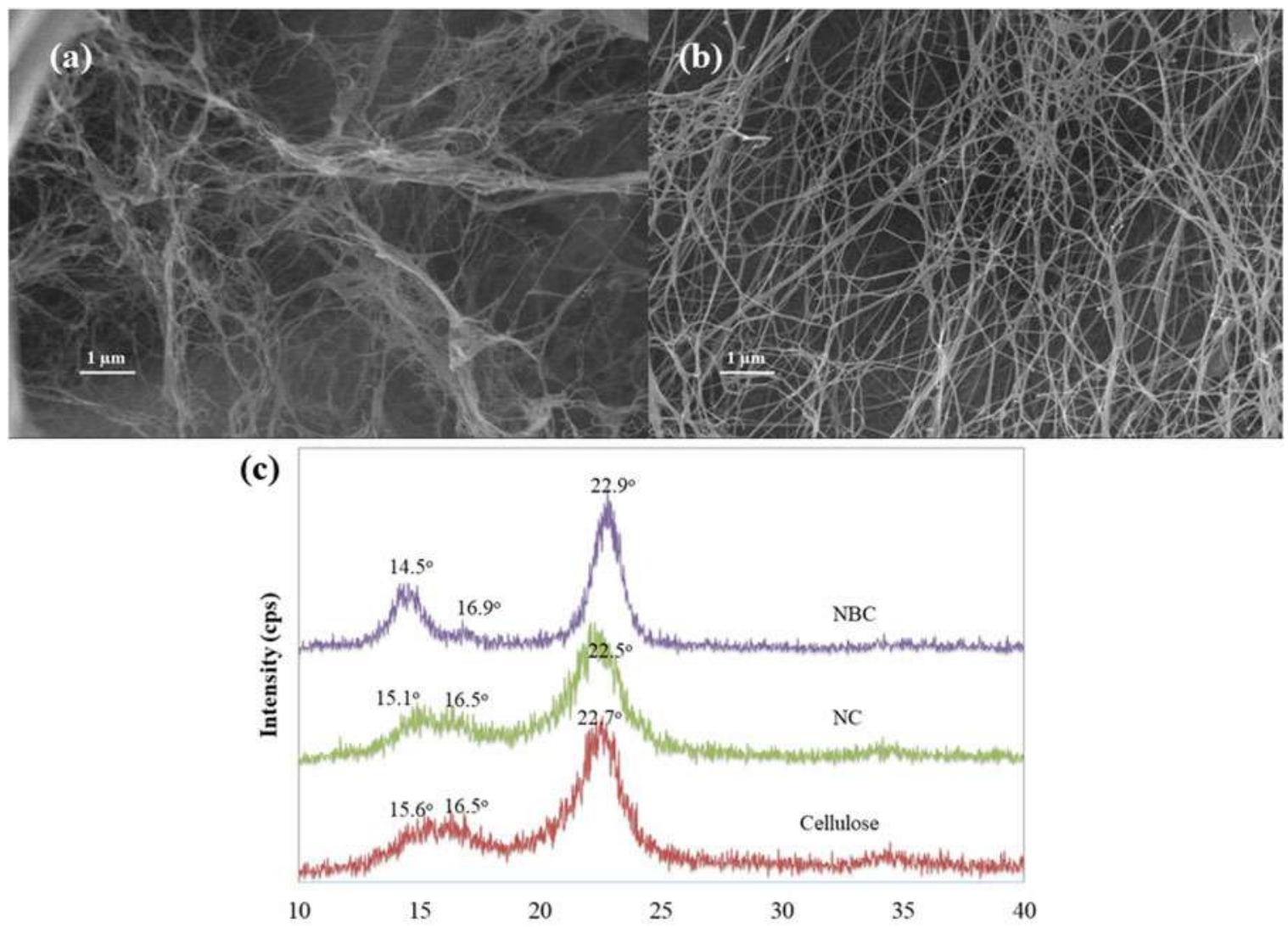

$2 \theta$

Figure 1. SEM images of NC from OPEFBs (a) and NBC (b), XRD profile of nano-sized bacterial cellulose (NBC), nanocellulose (NC) and cellulose (c).

reflections between 15.0 and $15.6^{\circ}, 16.3$ and $16.5^{\circ}$ and 22.3 and 22.6 $6^{\circ}$ respectively (Zhao, Moser, Lindstrom, Henriksson, \& $\mathrm{Li}, 2017)$. This high crystallinity pattern was seen in nano-sized bacterial cellulose, which had three corresponding peaks in its XRD profile. The degree of crystallinity of NBC and NC from OPEFBs were $71.7 \pm 0.7 \%$ and $60.4 \pm 1.4 \%$, respectively, while the crystallinity of cellulose was $55.1 \%$. The mechanical treatment using a combination of ultrafine grinding and ultrasonication randomly breaks apart both crystalline and amorphous regions, which caused a decrease in the crystallinity of nanocellulose. This damage of cellulose crystals is believed to separate the bundles of fibrils to form nanofibers (Mtibe, Mokhothu, John, Mokhena, \& Mochane, 2018). The decrease in crystallinity occurred due to inter-molecular and intra-molecular hydrogen bonds of cellulose being broken, leading to depolymerisation of cellulose during the severe mechanical treatment (Phanthong et al., 2018).

\section{Morphology of nanocellulose-based spun-fibres}

All spun-fibres were successfully produced by a wet spinning method using an acetone coagulation bath. The fibres took several minutes to dehydrate in the acetone bath before forming sturdy fibres. The dehydration time of NC fibres was the longest compared to the others (around 15-20 min). The neat PVA fibre took 5-7 min to dehydrate, while all PVA-NC and PVA-NBC fibres took 10-15 min.
The surfaces and cross sections of the produced spunfibres were observed by SEM (Figure 2). The NC fibre (Figure 2(a)) appears to have a round and compact cross section. In contrast, the cross section of all PVA-NC (70:30, 80:20 and 90:10), PVA-NBC and neat PVA fibres have irregular circular shape and are hollow or display some porosity, (Figure 2(c-k)) with diameters ranging from 100 to 125 $\mu \mathrm{m}$. Porosity was believed to be caused by air trapped in the suspension during the wet spinning and coagulation processes (Hooshmand et al., 2015). From Figure 2(a,b), the wet spinning of nanocellulose seemed an effective technique for alignment in acetone coagulation. Iwamoto et al. (2011) also observed that the cross section of fibres spun from tunicate cellulose nanofibers had cylindrical shape with porous structures. The difference in cross section shape might also be related to the viscosity of the suspension. The higher the viscosity of the suspension, the less nanofibers moved upon dehydration in acetone coagulation bath. However, there are many factors that may affect the cross section morphology of filaments produced, including the spinning system, spinning rate, drawing ratio and coagulation bath composition.

The NC fibre (Figure 2(b)) also appeared to have a coarser and more fibrous structure than that of all PVANC, PVA-NBC and neat PVA fibres (Figure 2(d-l)). The surfaces of the PVA-NC, PVA-NBC and neat PVA fibres were smooth. The surface morphology of all produced spun-fibres was similar to that previously reported by Endo et al. (2013), where the morphological surface of a PVA/ 


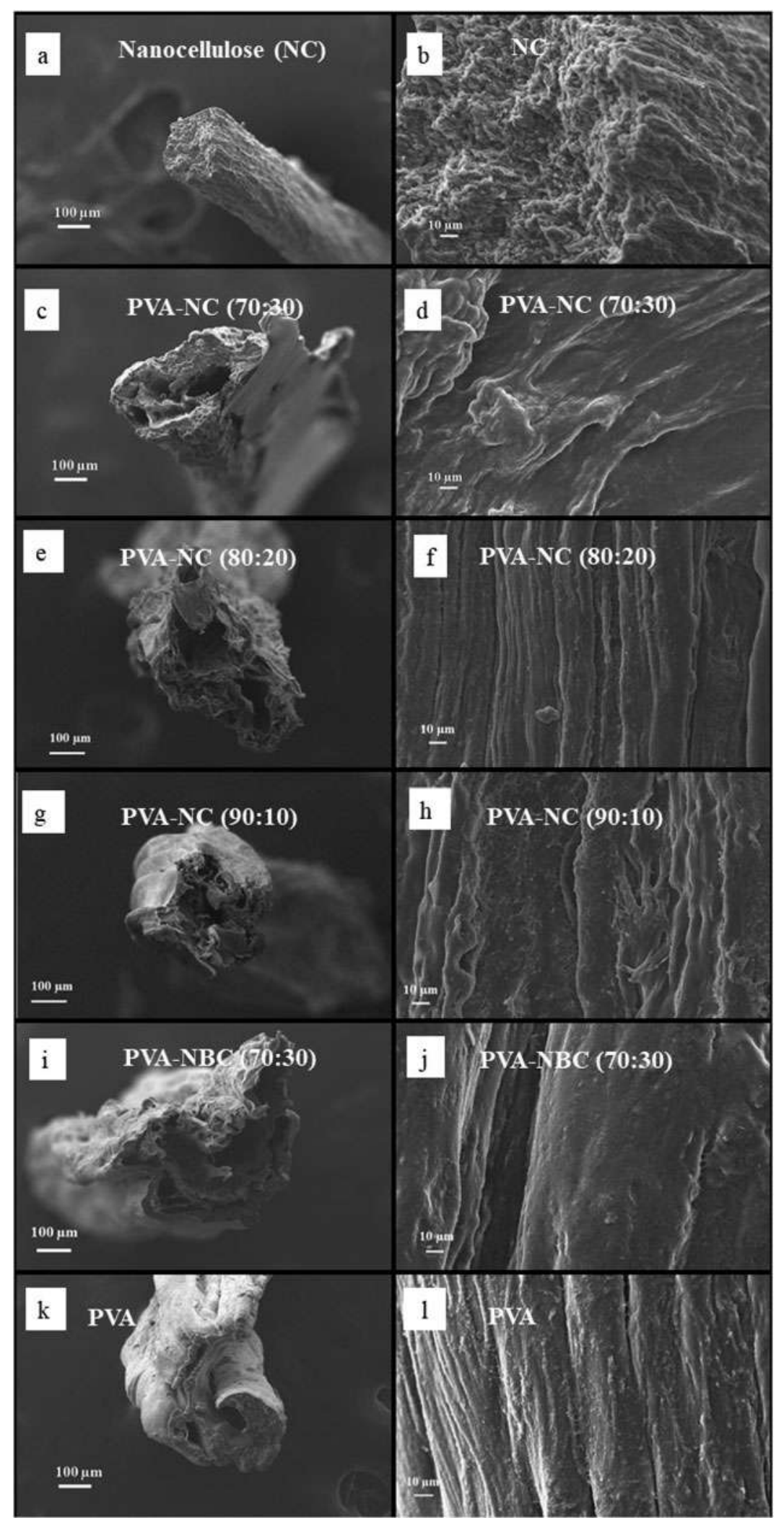

Figure 2. SEM images of the nanocellulose-based spun-fibres. The cross section and surfaces of the NC ( $a$ and b), PVA-NC 70:30 (c and d), PVA-NC 80:20 (e and f), PVA-NC 90:10 ( $\mathrm{g}$ and $\mathrm{h}$ ), PVA-NBC ( $\mathrm{a}$ and $j$ ) and PVA fibers ( $k$ and $\mathrm{l}$ ).

TOCN (TEMPO-oxidized cellulose nanofibers) composite smooth and homogenous, nearly identical to the PVA drawn fibre. The diameter of fibres observed was $20.6 \pm 0.0$ $\mu \mathrm{m}$. However, the result obtained from Peng et al. (2014) showed that PVA/SCNF (short cellulose nanofibrils) had an irregular surface and circular cross section with diameters ranging from 45 to $55 \mu \mathrm{m}$. Both diameters were smaller than the diameters of our produced spun-fibres. 


\section{X-ray analysis}

The XRD profiles of all spun-fibres are shown in Figure 3. The neat PVA fibre did not show a crystalline peak but rather an amorphous peak located at $2 \theta=19.5^{\circ}$. PVA-NC composite fibres displayed a clear peak near $2 \theta=19.5^{\circ}$, with an additional peak at $2 \theta=22.5^{\circ}$ becoming visible with increasing NC content from $10 \%$ to $30 \%$. This peak is attributed to the nanocellulose structure pattern increasingly being formed. With $10 \% \mathrm{NC}$, the peak at $22.5^{\circ}$ is not visible. At $20 \% \mathrm{NC}$, the peak at $19.5^{\circ}$ shifted to $19.8^{\circ}$ and the peak at $22.5^{\circ}$ appears as a shoulder, although its intensity is low. Once the fibre reaches $30 \% \mathrm{NC}$, the intensity of the peak at $2 \theta=22.5^{\circ}$ is clearly above the noise. This shows that with the addition of NC up to $30 \%$, the degree of crystallinity of the composite fibre (PVA-NC) increased. The XRD profile of PVA-NBC (70:30) also showed two peaks located at $2 \theta=19.5^{\circ}$ and $22.5^{\circ}$ assigned to PVA and cellulose patterns. Its degree of crystallinity was lower than that of PVA-NC (70:30).

Peng et al. (2014) found that the addition of up to $2-3 \%$ SCNF slightly increased the degree of crystallinity of fibres from 62.8 to $63.0 \%$, whereas the addition of SCNF at higher concentration resulted in lower degree of crystallinity. However, the neat PVA fibre still had the highest degree of crystallinity compared to PVA/SCNF fibres which was $64.4 \%$. The addition of SCNF at a higher concentration probably reduced the orientation due to the formation of SCNF networks that inhibit molecular alignment. Overall, there was no significant difference in the degree of crystallinity values obtained. A similar trend was also observed by Endo et al. (2013), where there was no significant difference in the PVA crystallite orientation of neat PVA and PVA/ TOCN fibres. The diffraction peaks of neat PVA and PVA/ SCNF or PVA/TOCN were not reported in either study.

\section{Mechanical properties}

Table 1 shows the mechanical properties of all produced spun-fibres. The tensile strength of our spun NC fibre was lower than that of spun-fibre produced by Iwamoto et al. (2011). This might be due to the difference in crystallinity of wood and OPEFBs. This result was also quite small compared to that obtained by Peng et al. (2014), where the tensile strength of pure PVA and PVA/SCNF ranges from 525 to $868 \mathrm{MPa}$ with modulus ranges from 10 to $32 \mathrm{GPa}$. When compared to Endo et al. (2013), this result was far lower, where the tensile strength and modulus achieved by addition of only $1 \%$ TOCN to PVA was $1.6 \mathrm{GPa}$ and $57 \mathrm{GPa}$, respectively.

Endo et al. (2013) and Peng et al. (2014) produced spunfibres with a combination of wet spinning, drawing and drying, while we produced spun-fibre without drawing. We used nanocellulose isolated from OPEFB, which has characteristics that differ from those of nanocellulose from other sources used in these studies. In addition, we also used higher nanocellulose content.

According to Moon, Martini, Nairn, Simonsen, and Youngblood (2011), there are several factors that affect the

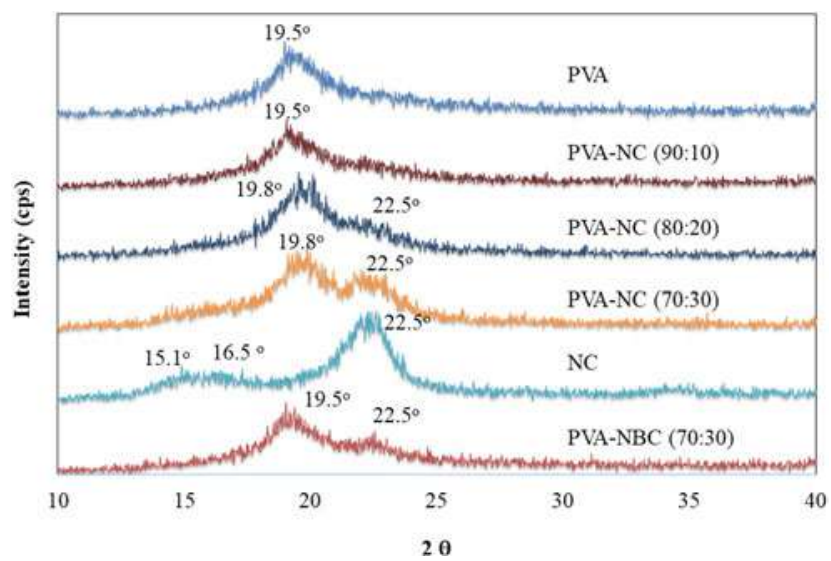

Figure 3. XRD profiles of nanocellulose-based spun-fibres.

mechanical properties of nanocellulose, including crystal structure, crystallinity, anisotropy, defects and isolation approaches. In addition, the choice of isolation method generally has a strong effect on the crystallinity of the nanocellulose. Cellulose nanofibers (CNF) isolated by mechanical treatment contain both amorphous and crystalline regions and usually have a high aspect ratio. In contrast, cellulose nanocrystals (CNC) isolated by acid hydrolysis have almost no amorphous fraction remaining. Importantly, higher crystallinity nanocellulose tends to produce fibres with better mechanical properties.

The lowest elongation at break was the spun NC fibre, at 3.36\%. This was because PVA has good tensile strength and plastic properties while nanocellulose does not, leading to facile breaking. The nanocellulose dispersed well in the PVA solution, producing a PVA composite fibre with good homogenisation and a spun-fibre with a high tensile strength. The addition of NC and NBC into the PVA matrix, however, led to a decrease in tensile strength and elongation at break in the spun composite fibre. This might be because the addition of NC (up to $30 \%$ ) or NBC increased the stiffness of the spun composite fibre significantly. Peng et al. (2014) stated that such a decrease in tensile strength of fibres may be caused by the orientation of the crystalline PVA being interrupted as result of nanocellulose network formation, which limit the molecular alignment.

Table 2 shows the mechanical properties of all produced spun-fibres in wet condition. This mechanical property test was performed shortly after the spun-fibres were immersed in distilled water for $2 \mathrm{~h}$. Wet fibre testing was carried out to determine whether there was a change in the mechanical properties when the fibre was hydrated. In general, when the fibre was wet, the tensile strength and modulus of spunfibres decreased significantly while the elongation at break increased. This is likely because wet conditions caused the mixture of PVA and nanocellulose to swell (Figure 4) allowing the spun-fibre to stretch more easily when pulled in the tensile test.

\section{Swelling degree}

The swelling degree of nanocellulose-based spun-fibres is shown in Figure 4. The highest swelling degree was PVA- 
Table 1. Mechanical properties of all produced spun-fibres (dried fibres).

\begin{tabular}{|c|c|c|c|c|c|c|}
\hline Samples & Tensile strength (MPa) & SD & Tensile modulus (MPa) & SD & Elongation at break (\%) & SD \\
\hline PVA & 93.57 & 7.32 & 76.42 & 57.97 & 177.02 & 143.88 \\
\hline NC & 47.29 & 2.08 & 1534.60 & 656.17 & 3.36 & 1.30 \\
\hline PVA-NBC (70:30) & 53.77 & 4.83 & 264.94 & 45.63 & 20.44 & 1.70 \\
\hline PVA-NC (70:30) & 31.82 & 2.16 & 236.34 & 3.65 & 13.46 & 0.71 \\
\hline PVA-NC (80:20) & 31.05 & 1.63 & 396.00 & 37.34 & 11.32 & 3.62 \\
\hline PVA-NC (90:10) & 21.18 & 1.60 & 136.75 & 39.01 & 16.32 & 5.83 \\
\hline
\end{tabular}

Table 2. Mechanical properties of all produced spun-fibres in wet condition.

\begin{tabular}{|c|c|c|c|c|c|c|}
\hline Samples & Tensile strength (MPa) & SD & Tensile modulus (MPa) & SD & Elongation at break (\%) & SD \\
\hline PVA & 63.6 & 11.20 & 24.17 & 4.35 & 296.43 & 7.07 \\
\hline NC & 28.52 & 24.60 & 912.49 & 249.84 & 2.86 & 0.42 \\
\hline PVA-NBC (70:30) & 19.29 & 3.15 & 76.64 & 10.97 & 59.2 & 1.41 \\
\hline PVA-NC (70:30) & 17.56 & 4.12 & 65.53 & 15.70 & 49.48 & 18.15 \\
\hline PVA-NC (80:20) & 14.59 & 0.01 & 54.43 & 0.12 & 46.08 & 8.71 \\
\hline PVA-NC (90:10) & 16.63 & 2.30 & 48.86 & 48.91 & 47.75 & 25.23 \\
\hline
\end{tabular}

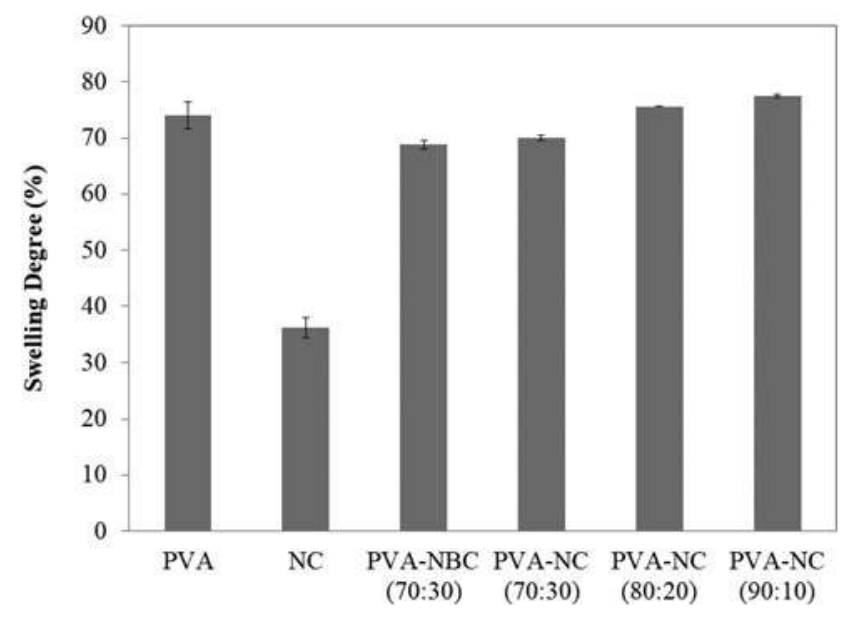

Figure 4. Swelling degree of nanocellulose-based spun-fibres.

NC (90:10) fibre (77.55\%), followed by PVA-NC (80:20) fibre $(75.60 \%)$ and neat PVA fibre $(74.05 \%)$. The lowest swelling degree was NC fibre (36.25\%). The addition of nanocellulose can reduce the swelling degree of the fibre as found in the PVA-NC (70:30) (69.99\%) fibre and PVA-NBC (70:30) fibre $(68.80 \%)$. Swelling degree can affect the tensile strength of fibres in wet condition (Table 2). The higher the swelling degree of the fibre the smaller its mechanical properties. The spun-fibre is expected to still have good tensile strength even though it is wet because it will be difficult to use if the fibre has a high swelling degree and is easily broken. Figure 4 shows that with addition of nanocellulose up to $30 \%$ and NBC, the swelling degree of PVA matrix decreased.

\section{Thermal stability}

Figure 5 shows that each produced spun-fibre has a distinct thermal decomposition profile. NC, PVA-NC (70:30) and PVA-NC (80:20) fibres showed gradual thermal transitions with broader temperature range than neat PVA, PVA-NC (90:10) and PVA-NBC fibres. Based on thermal behaviour, the thermal stability of NC fibre and PVA-NC fibre with high nanocellulose content (20\% and 30\%) is higher than that of neat PVA and PVA-NBC fibres. This suggests the

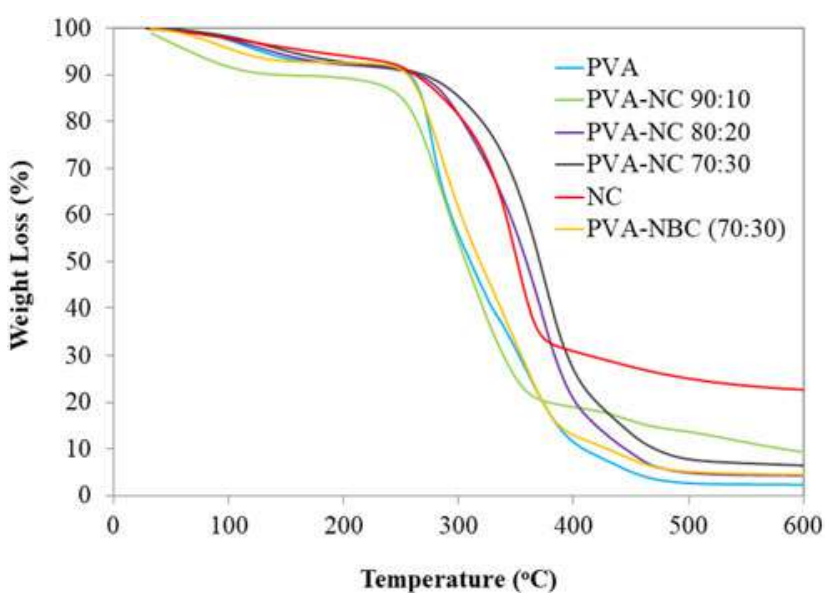

Figure 5. TGA profiles of nanocellulose-based spun-fibres.

existence of strong, mutually reinforcing interactions between PVA and NC through the interaction of hydroxyl $(-\mathrm{OH})$ groups (Figure 6). PVA-NBC fibre also showed an increase in thermal resistance when compared to neat PVA fibre.

All samples appear to have undergone two stages of thermal degradation. The first degradation occurred at temperatures below $200{ }^{\circ} \mathbf{C}$, which is due to the evaporation of physically and chemically bonded water, or other volatile components found in the sample (Chen \& Wang, 2002). At the second stage of degradation, NC fibre lost $60 \%$ mass at $361{ }^{\circ} \mathrm{C}$, PVA-NC (70:30) at $381{ }^{\circ} \mathrm{C}$, PVA-NC (80:20) fibre at $343{ }^{\circ} \mathrm{C}$, PVA-NC (90:10) fibre at $291{ }^{\circ} \mathrm{C}$, PVA-NBC fibre at $337^{\circ} \mathbf{C}$ and neat PVA fibre at $329^{\circ} \mathbf{C}$. This degradation is likely pyrolysis of nanocellulose and the degradation of the PVA matrix, which involves dehydration reactions and formation of volatile products (Qua, Hornsby, Sharma, Lyons, \& McCall, 2009).

The TGA curves indicate that the NC fibre showed the highest thermal stability, while the neat PVA fibre showed the lowest thermal stability, which was proven by the highest mass residue of NC compared to PVA at $600{ }^{\circ} \mathrm{C}$. With the addition of nanocellulose, PVA-NC composite fibre had a higher thermal stability than that of the neat PVA fibre. This shows that the nanocellulose added was dispersed well without any significant aggregation, thus causing a delay in 
the thermal degradation of PVA. Nanocellulose also helped prevent out-diffusion of volatile decomposition products. When the nanocellulose is well dispersed in PVA matrix it acts as a barrier for vapour diffusion; thus, vapour does not pass through the crystal structure of PVA (Fahma, Hori, Iwata, \& Takemura, 2013). At $600{ }^{\circ} \mathrm{C}$, NC fibre produced $22.6 \%$ residue, PVA-NC (70:30) fibre 6.4\%, PVA-NC (80:20) fibre 4.3\%, PVA-NC (90:10) fibre 9.3\%, PVA-NBC fibre $4.5 \%$ and neat PVA fibre $2.3 \%$.

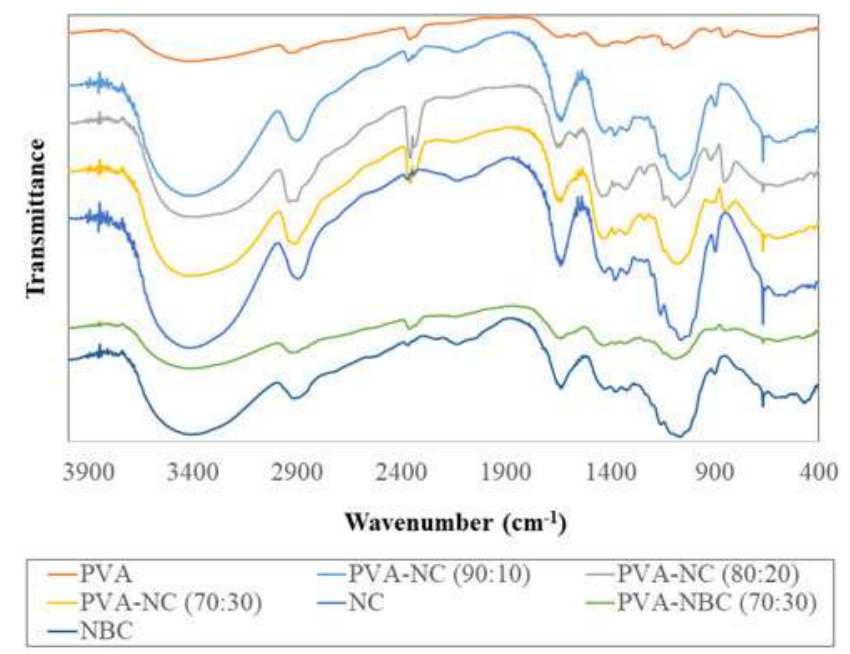

Figure 6. FTIR profiles of nanocellulose-based spun-fibres.

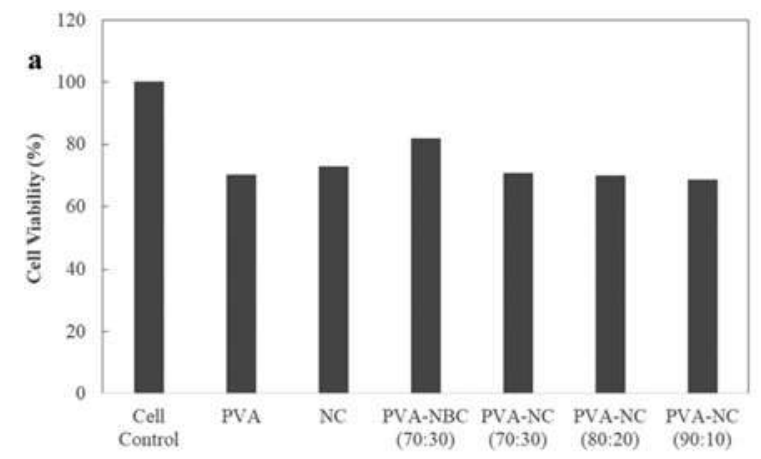

Figure 7. Cell viability by MTT assay for 1 week (a) and 2 weeks (b).

\section{FTIR analysis}

An FTIR analysis was performed to identify the chemical groups of the spun-fibres. The FTIR spectra of all produced spun-fibres are shown in Figure 6. Wide absorption peaks were found at $3421 \mathrm{~cm}^{-1}, 3419 \mathrm{~cm}^{-1}$ and $3410 \mathrm{~cm}^{-1}$ corresponding to stretching vibrations of $\mathrm{O}-\mathrm{H}$ groups found in $\mathrm{NC}, \mathrm{NBC}$ and neat PVA fibres. After the addition of NC and NBC, the stretching vibration of the $\mathrm{O}-\mathrm{H}$ groups in neat PVA fibre was shifted to $3415 \mathrm{~cm}^{-1}$, which indicates the probable interaction of PVA and NC fibres as well as PVA and NBC fibres. The absorption of $\mathrm{O}-\mathrm{H}$ groups was also increased after the addition of NC and NBC, suggesting hydrogen bonding between the components.

At $2900 \mathrm{~cm}^{-1}$, the stretching vibration of the $\mathrm{C}-\mathrm{H}$ groups was also observed in all spun-fibres. At $1639 \mathrm{~cm}^{-1}$, a peak suggesting the presence of $\mathrm{O}-\mathrm{H}$ bending of the absorbed water can be clearly seen (Zain, Yusop, \& Ahmad, 2014). In the spectra of NC, NBC, PVA-NC and PVA-NBC fibres, the peak at $1429 \mathrm{~cm}^{-1}$ is related to the asymmetric angular deformation of $\mathrm{C}-\mathrm{H}$ bonds (Vasconcelos et al., 2017). A small peak observed at $1160 \mathrm{~cm}^{-1}$ was believed to be related to the pyranose ring $\mathrm{C}-\mathrm{O}-\mathrm{C}$ asymmetric stretching of cellulose. The band found at $1060 \mathrm{~cm}^{-1}$ shows $\mathrm{C}-\mathrm{O}$ and $\mathrm{C}-\mathrm{H}$ stretching vibrations, which confirm the structure of cellulose (Zain et al., 2014). The peak observed at $897 \mathrm{~cm}^{-1}$ indicates the presence of b-glycosidic bonds in the glucose ring

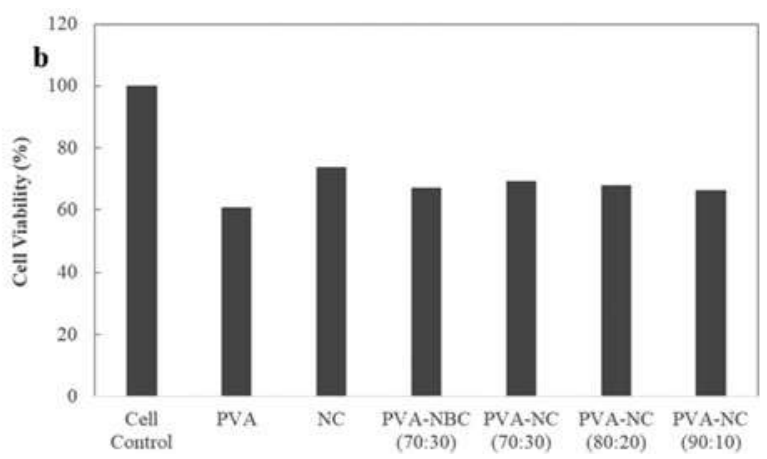

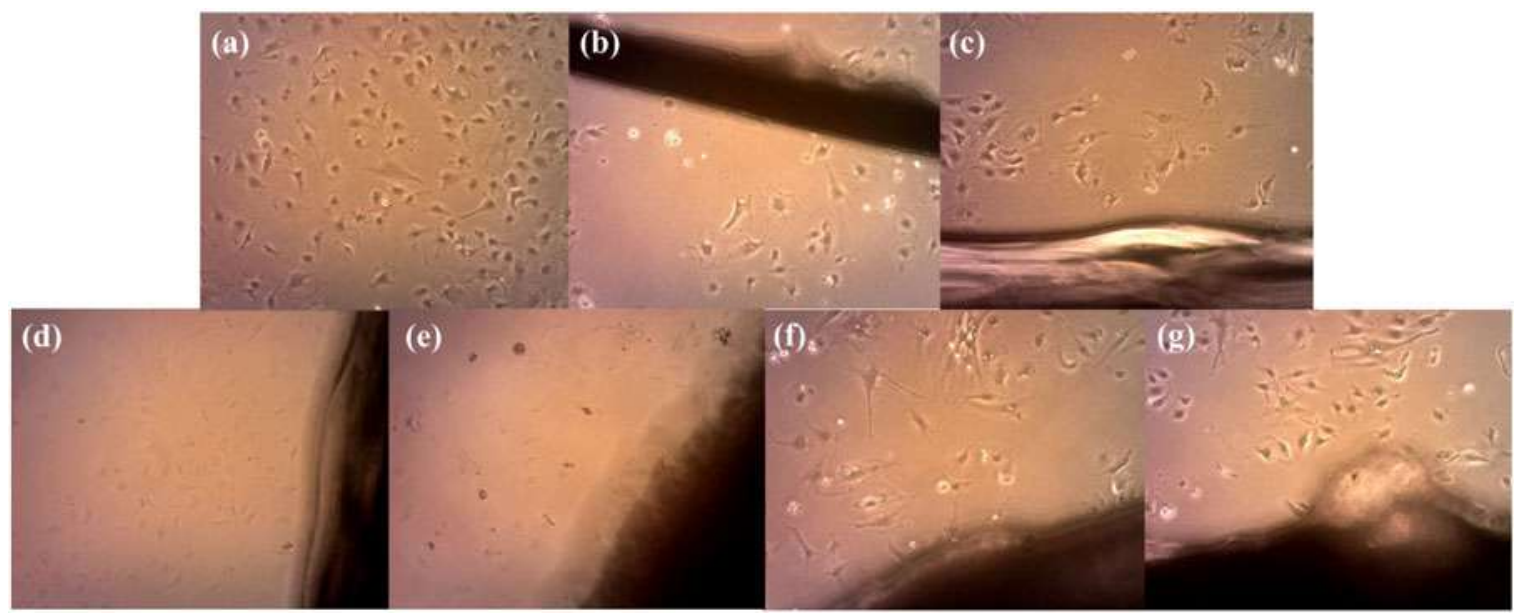

Figure 8. Appearance of cell viability due to nanocellulose-based spun-fibres analysed by MTT for 1 week: (a) control, (b) NC, (c) PVA, (d) PVA-NC (90:10), (e) PVANC (80:20), (f) PVA-NC (70:30) and (g) PVA-NBC. 
of NC and NBC (Borsoi, Ornaghi, Scienza, Zattera, \& Ferreira, 2017).

In neat PVA, absorption at $1431 \mathrm{~cm}^{-1}$ is due to bending vibrations of $\mathrm{CH}-\mathrm{OH}$ group (Ling, Qi, Knight, Shao, \& Chen, 2013), while the small peak at $1143 \mathrm{~cm}^{-1}$ was assigned to the crystalline structure of PVA. The stretching of C-O groups was also found at $1097 \mathrm{~cm}^{-1}$ in the PVA spectrum, which was assigned as a secondary alcohol (Lobo \& Bonilla, 2003). The peak at $850 \mathrm{~cm}^{-1}$ showed the presence of C-C stretching vibration in PVA (El Miri et al., 2015).

\section{In vitro biocompatibility}

The in vitro biocompatibility of nanocellulose-based spunfibres was evaluated by MTT assays. The MTT assay was performed with two different soaking time periods: 7 and 14 days. From Figure 7, it can be concluded that the materials soaked for 2 weeks had a smaller number of living cells than those tested in the 1-week immersion liquid. Cells that had longer exposure time to the immersion liquid produced fewer living cells. Based on the MTT assay, all spun-fibres had more than $50 \%$ cell viability until 2 weeks. The increased cell viability due to nanocellulose inclusion in spun-fibres is shown in Figure 8. The NC fibre did not show any difference in cell viability between a 7-day or 14day test period. The other fibres, however, showed a decrease in the cell viability from soaking for 7 days to a 14 day immersion. After a 7 day immersion, PVA-NBC fibre had a cell viability of $81.69 \%$, while at 14 days the viability decreased to $67.28 \%$. The PVA-NC (70:30) fibre showed a decrease in cell viability from $70.58 \%$ at 7 days immersion to $69.34 \%$ at 14 day immersion. Similarly, spun-fibre cell viability decreased from $69.96 \%$ to $67.9 \%$ for PVA-NC (80:20) fibre and from $68.52 \%$ to 66.26 for PVA-NC (90:10) fibre, after the additional 7-day soak. Clearly, the nanocellulose was able to maintain cell viability for 14 days. In the control study, living cells were evenly distributed throughout the cell medium (Figure 8(a)). After any spun-fibre was contacted with the cell, the number of living cells decreased (Figure 8). Therefore, while all fibres caused damage to living cells, nanocellulose-based fibres maintained more viable cell conditions.

\section{Conclusion}

Nanocellulose-based filaments were successfully produced by wet spinning. The nanocellulose was isolated from oil palm empty fruit bunches (OPEFBs) by mechanical treatment using a combination of ultrasonication and ultrafine grinding. Scanning electron microscopy (SEM) revealed that the spun nanocellulose fibre was compact (non-hollow), while all PVA-nanocellulose fibres had hollow, porous structures. The spun nanocellulose fibre had a tensile strength of $47.29 \pm 2.08 \mathrm{MPa}$, modulus Young's of $1.5 \pm 0.66 \mathrm{GPa}$ and elongation at break of $3.36 \pm 1.3 \%$. In contrast, the neat PVA fibre had the highest tensile strength and elongation compared to other spun-fibres. With the addition of nanocellulose up to $30 \%$, the tensile strength of the produced spun-fibre increased, although it was still smaller than the neat PVA fibre. The PVA-nano-sized bacterial cellulose fibres had tensile strength $53.77 \pm 4.83 \mathrm{MPa}$, which was higher than that of PVA-nanocellulose fibres. Generally, all PVA-nanocellulose fibres had higher swelling degrees than the nanocellulose fibre. In vitro biocompatibility evaluation based on the MTT test showed that when it was compared with the spun PVA fibre, the presence of nanocellulose in spun-fibres did not have a significant effect on cell viability. In vitro biocompatibility assay by the MTT test also showed that cells grew more than 50\% around all nanocellulosebased spun-fibres. Given the increased cell viability and moderate tensile strength retention, nanocellulose from OPEFBs are shown to be a promising and environmentally friendly fibre additive for medical applications.

\section{Acknowledgement}

Authors would like to thank to Kementrian Riset Teknologi dan Pendidikan Tinggi Republik Indonesia and IPB University for financial support (Riset Kolaborasi Indonesia - WCU/World Class University 2018) (Contract no. 0760/IT3.11/PN/2018). Authors also would like to thank to Miss Ida Febiyanti for technical support.

\section{Disclosure statement}

No potential conflict of interest was reported by the authors.

\section{ORCID}

Farah Fahma (D) http://orcid.org/0000-0003-3690-1217 Deni Noviana (iD http://orcid.org/0000-0001-9496-0130 Yessie Widya Sari (D) http://orcid.org/0000-0001-9944-2965 Rino R. Mukti (DD http://orcid.org/0000-0003-4193-1066 Muchammad Yunus (D) http://orcid.org/0000-0001-7516-6628 Ahmad Kusumaatmaja (D) http://orcid.org/0000-0001-5459-4754 Grandprix Thomryes Marth Kadja (D) http://orcid.org/0000-00030264-2739

\section{References}

Borsoi, C., Ornaghi, H. L. Jr., Scienza, L. C., Zattera, A. J., \& Ferreira, C. A. (2017). Isolation and characterisation of cellulose nanowhiskers from microcrystalline cellulose using mechanical processing. Polymers and Polymer Composites, 25, 563-570.

Chen, H., \& Wang, Y. (2002). Preparation of MCM-41 with high thermal stability and complementary textural porosity. Ceramics International, 28, 541-547. doi:10.1016/S0272-8842(02)00007-X

El Miri, N., Abdelouahdi, K., Zahouily, M., Fihri, A., Barakat, A., Solhy, A., \& El Achaby, M. (2015). Bio-nanocomposite films based on cellulose nanocrystals filled polyvinyl alcohol/chitosan polymer blend. Journal of Applied Polymer Science, 132, n/a-13.

Endo, R., Saito, T., \& Isogai, A. (2013). TEMPO-oxidized cellulose nanofibril/poly(vinyl alcohol) composite drawn fibers. Polymer, 54, 935-941. doi:10.1016/j.polymer.2012.12.035

Fahma, F., Hori, N., Iwata, T., \& Takemura, A. (2013). The morphology and properties of poly(methyl methacrylate)-cellulose nanocomposites prepared by immersion precipitation method. Journal Applied Polymer Science, 128, 1563-1568.

Fahma, F., Iwamoto, S., Hori, N., Iwata, T., \& Takemura, A. (2010). Isolation, preparation, and characterization of nanofibers from oil palm empty-fruit-bunch (OPEFB). Cellulose, 17, 977-985. doi:10. 1007/s10570-010-9436-4 
Fahma, F., Sugiarto Sunarti, T. C., Indriyani, S. M., \& Lisdayana, N. (2017). Thermoplastic cassava starch-PVA composite films with cellulose nanofibers from oil palm empty fruit bunches as reinforcement agent. International Journal of Polymer Science, 2017, 5p. Article ID 2745721. doi:10.1155/2017/2745721

Håkansson, K. M. O., Fall, A. B., Lundell, F., Yu, S., Krywka, C., Roth, S. V., ... Söderberg, L. D. (2014). Hydrodynamic alignment and assembly of nanofibrils resulting in strong cellulose filaments. Nature Communications, 5, 4018.

Hooshmand, S., Aitomäki, Y., Norberg, N., Mathew, A. P., \& Oksman, K. (2015). Dry-spun single-filament fibers comprising solely cellulose nanofibers from bioresidue. ACS Applied Materials and Interfaces, 7, 13022-13028.

Iwamoto, S., Isogai, A., \& Iwata, T. (2011). Structure and mechanical properties of wet-spun fibers made from natural cellulose nanofibers. Biomacromolecules, 12, 831-836.

Ling, S., Qi, Z., Knight, D. P., Shao, Z., \& Chen, X. (2013). FTIR imaging, a useful method for studying the compatibility of silk fibroinbased polymer blends. Polymer Chemistry, 21, 5401-5406. doi:10. 1039/c3py00508a

Lobo, H., \& Bonilla, J. V. (2003). Handbook of plastics analysis. New York, NY: Marcel Dekker, Inc.

Lundahl, M. J., Cunha, A. G., Rojo, E., Papageorgiou, A. C., Rautkari, L., Arboleda, J. C., \& Rojas, O. J. (2016). Strength and water interactions of cellulose I filaments wet-spun from cellulose nanofibril hydrogels. Scientific Reports, 6, 30695.

Masahiro, N., Megumi, I., Kazuhiko, J., Hitoshi, S., \& Takaichi, A. (1980). Sustained urinary excretion of sulfamethizole following oral administration of enteric coated microcapsules in humans. International Journal of Pharmaceutics, 4, 291-298. doi:10.1016/ 0378-5173(80)90004-6

Ministry of Agriculture - Sekretariat Jenderal. (2016). Outlook Kelapa Sawit. Jakarta: Pusat Data dan Sistem Informasi Pertanian, Kementrian Pertanian.

Moon, R. J., Martini, A., Nairn, J., Simonsen, J., \& Youngblood, J. (2011). Cellulose nanomaterials review: Structure, properties and nanocomposites. Chemical Society Reviews, 40, 3941-3994.

Mtibe, A., Mokhothu, T. H., John, M. J., Mokhena, T. C., \& Mochane, M. J. (2018). Fabrication and characterization of various engineered nanomaterials. In C. Mustansar Hussain (Ed.), Handbook of nanomaterials for industrial applications, Micro and Nano Technologies Series (pp. 151-171, Chap. 8). Elsevier. doi:10.1016/B978-0-12813351-4.00009-2.

Nasir, M., Hashim, R., Sulaiman, O., \& Asim, M. (2017). Nanocellulose: Preparation methods and applications in cellulosereinforced nanofibre composites. In M. Jawaid, S. Boufi, \& A. H. P. S. Khalil (Eds.). WP Woodhead Publishing. doi:10.1016/B978-0-08100957-4.00011-5
Nguyen, T. H. M., Abueva, C., Ho, H. V., Lee, S. Y., \& Lee, B. T. (2018). In vitro and in vivo acute response towards injectable thermosensitive chitosan/TEMPO-oxidized cellulose nanofiber hydrogel. Carbohydrate Polymers, 180, 246-255. doi:10.1016/j.carbpol.2017.10. 032

Peng, J., Ellingham, T., Ron-Sabo, R., Turng, L. S., \& Clemons, C. M. (2014). Short cellulose nanofibrils as reinforcement in polyvinyl alcohol fiber. Cellulose, 21, 4287-4298. doi:10.1007/s10570-0140411-3

Phanthong, P., Reubroycharoen, P., Hao, X., Xu, G., Abudula, A., \& Guan, G. (2018). Nanocellulose: Extraction and application. Carbon Resources Conversion, 1, 32-43. doi:10.1016/j.crcon.2018.05.004

Qua, E. H., Hornsby, P. R., Sharma, H. S., Lyons, G., \& McCall, R. D. (2009). Preparation and characterization of poly(vinyl alcohol) nanocomposites made from cellulose nanofibers. Journal of Applied Polymer Science, 113, 2238-2247. doi:10.1002/app.30116

Rohaizu, R., \& Wanrosli, W. D. (2017). Sono-assisted TEMPO oxidation of oil palm lignocellulosic biomass for isolation of nanocrystalline cellulose. Ultrasonics Sonochemistry, 34, 631-639. doi:10.1016/j. ultsonch.2016.06.040

Seabra, A. B., Bernardes, J. S., Fávaro, W. J., Paula, A. J., \& Durán, N. (2018). Cellulose nanocrystals as carriers in medicine and their toxicities: A review. Carbohydrate Polymers, 181, 514-527. doi:10.1016/ j.carbpol.2017.12.014

Spencer, P. C., Schmidt, B., Samtleben, W., Bosch, T., \& Gurland, H. J. (1985). Ex vivo model of hemodialysis membrane biocompatibility. Transactions - American Society for Artificial Internal Organs, 31, 495-498.

Sun, B. R. C., Fang, J. M., Mott, L., \& Bolton, J. (1999). Fractional isolation and characterization of polysaccharides from oil palm trunk and empty fruit bunch fibres. Holzforschung, 53, 253-260. doi:10. 1515/HF.1999.043

Vasconcelos, N. F., Feitosa, J. P. A., Portela da Gama, F. M., Morais, J. P. S., Andrade, F. K. Filho, M. S. M. S., \& Rosa, M. F. (2017). Bacterial cellulose nanocrystals produced under different hydrolysis conditions: Properties and morphological features. Carbohydrate Polymers, 155, 425-431. doi:10.1016/j.carbpol.2016.08.090

Wang, B., Sain, M., \& Oksman, K. (2007). Study of structural morphology of hemp fiber from the micro to the nanoscale. Applied Composite Materials, 14, 89-103. doi:10.1007/s10443-006-9032-9

Zain, N. F. M., Yusop, S. M., \& Ahmad, I. (2014). Preparation and characterization of cellulose and nanocellulose from pomelo (citrus grandis) albedo. Journal of Nutrition and Food Sciences, 5(1), 1-4.

Zhao, Y., Moser, C., Lindstrom, M. E., Henriksson, G., \& Li, J. (2017). Cellulose nanofibers (CNF) from softwood, hardwood and tunicate: Preparation-structure-film performance interrelation. ACS Applied Materials and Interfaces, 9, 13508-13519. doi:10.1021/acsami. $7 \mathrm{~b} 01738$ 